\title{
Effect of Inflation on Sri Lankan Banks' Performance: Mediation Effect of Interest Income and Expenses
}

\author{
B. W. C. M. Amarasena and T. U. I. Peiris
}

\section{ABSTRACT}

This study hypothesizes that the inflationary effects on bank performance are not straightforward but mediates through interest income and expenditure. This hypothesis is tested in the Sri Lankan context, referring to 17 licensed banks from 2011 to 2019. Findings were obtained using the Seemingly Unrelated Regression (SURE) model, and the results were tested for robustness by applying Three-Stage Least Squares Regression (3SLS) model. Results indicated that interest expenses negatively significant as a mediator between inflation and banks' performance. In contrast, the effect of interest income is positive. Therefore, a significantly negative overall effect can be expected because interest expenses are relatively more substantial than the influence of interest income on the banks' performance. Furthermore, although banks with excess savings can grant loans to the customers, customers are reluctant to gain the loans because they have to spend more interest in an inflationary situation.

Keywords: Banks' Performance, Inflation, Interest Expenses, Interest Income, Mediation Effect.
Submitted : May 25, 2021

Published : June 15, 2021

ISSN: 2507-1076

DOI: $10.24018 /$ ejbmr.2021.6.3.896

B.W.C.M. Amarasena*

Sabaragamuwa University of Sri Lanka, Belihuloya, Sri Lanka.

(e-mail: madushaamarasena.1992@ gmail.com)

T. U. I. Peiris

Sabaragamuwa University of Sri Lanka, Belihuloya, Sri Lanka.

(e-mail: tuipeiris@gmail.com)

*Corresponding Author

\section{INTRODUCTION}

Macroeconomic factors play a significant role in determining banks' performance. Herein, inflation is considered a substantial determinant of banks' performance, as demonstrated by the Positivists', Negativists', and Neutralists' theories in this regard. Positivists' Theory argues that inflationary effects are positively significant on the investment decision of organizations. Thus, it encourages investments in an economy and, in turn, will positively affect banks' performance as investors use bank loans in leveraging the organizations. This argument is empirically confirmed by other scholars of [1], [2], and [3].

In contrast, the Negativists' Theory indicates that inflation discourages savings and thereby reduces investments. Similarly, [4] suggests that inflation reduces investments as it lowers the value of money and increases risk. Furthermore, [5] emphasizes that increases in uncertainty due to inflation make investors reluctant to invest in long-term commitments. Therefore, it has the potential to negatively influencing bank performance. Several previous studies provide shreds of evidence in this regard as well. For instance, [6] indicates that significant inflationary effects negatively affect banks' profitability in the Philippines. Reference [7] confirms it for the Indian banks. Meanwhile, Neutralists' Theory asserts that inflation has no significant effect on investments. Therefore, it may not significantly influence the bank performance also.

Previous studies that concentrated on the inflationary effects of bank performance examined the direct impact of inflation and supported either Positivists' or Negativists' Theory depending on the results. However, this study argues that the sign of the total effect mainly depends on how inflation affects the interest income and the interest expense of a bank. According to the Positivists' Theory, inflation may affect positively as it expands the loan portfolio of a bank. In contrast, according to the Negativists theory, inflation may negatively affect the bank performance as it reduces the loan portfolio through contractions in savings. Meantime, reductions in savings may decrease interest expenses of a bank leading to a positive effect. Therefore, this study emphasizes the need to examine the mediation effects of interest income and interest expense when testing the impact of inflation on bank performance.

\section{LITERATURE REVIEW}

Positivists', Negativists', and Neutralists' theories on the relationship between inflation and banks' performance indicate a significant relationship between inflation and banks' performance.

Positivists' Theory expressed that inflation has a significant positive impact on the investment decision of organizations. Hence inflation tends to encourage investment. The chief proponent of this Theory was Griffiths [8]. He expressed that "inflation results in a more rapid economic growth as it tends to redistribute income from wages to profits for investment purposes. Hence, a widespread belief was that inflation and economic growth are positively and significantly related. When there is economic growth, it tends to redistribute income from wages to profits for investment purposes". So, as a result of creating wealth through a high number of investments, banks can gain high-interest income, leading to an increase in the banks' performance [9]. 
According to The Negativists' Theory, [10] asserts that "inflation is an enemy to savings, hence contributing adversely to firms' profitability position". Further to that, [4] confirms the above argument as inflation reduces the value of money and increases risk; hence, investments decrease. So, with the smaller number of investments, banks have not enough funds to grant more loans, which reduces the banks' performance due to low-interest income.

The Neutralists' Theory argues that "inflationary effects are not significant on investments, thereby carries no visible effect to banks' performance and it concluded that a firm's decision on investment is indifferent to inflationary effect [11].

In banking literature, the determinants of profitability are empirically well explored among various studies. Thereby, the bank profitability is typically measured by the return on assets (ROA) and the return on equity (ROE). According to [12] \& [13], ROA has emerged as a critical ratio for evaluating bank performance and has become the most common measure of bank performance.

Empirically, most developed countries and developing countries, including Sri Lanka, concentrated on the studies of determinants of banks' profitability and highlighted its direct effect.

According to developed countries' perspective, [1], who researched the determinants of profitability of domestic, commercial banks in the UK from 1995 to 2002, also indicate inflation has significant positive influences on the performance of banks. Reference [2] who researched China during 2003-2009 show a positive effect of inflation on banks' performance. They further imply that banks fully anticipated the inflation level and then adjust the interest rates accordingly.

According to the developing countries perspective, [3], who researched "Determinants of Commercial Bank Profitability in Malaysia," indicate that inflation positively impacted profitability. They further suggest that the ability of Bank management to predict inflation accurately can positively affect profitability as bank management can adjust interest rates in the desired direction to increase profit. But, the failure to accurately predict inflation could raise costs due to imperfect adjustment of interest rates and thus adversely affect the bank's profit.

Reference [6] researched "The factors that influence the profitability of commercial banks in the Philippines" during the 1990-2005 period. They concluded that the inflation rate is negatively related to the banks' profitability of the Philippines because the level of inflation was unanticipated by banks. They fail to adjust interest rates accordingly.

Reference [7] investigated the "Effect of inflation on banks performance in India." After analyzing data, they suggested that banks can absorb the effects of inflation at its initial stages since the banking system mainly operates concerning interest rates, ignoring the purchasing power of money. However, when inflation becomes more robust, the banking system cannot absorb the shocks. It has been observed that inflation harms banking sector performance and its spillover effects are detrimental to the overall economy.

Almost all previous researchers who concentrated on this relationship used a static model to regress inflation and banks' performance directly. However, the researcher hypothesizes that interest income and interest expenses mediate this relationship which is hardly tested in the previous literature. Therefore, this study was conducted to test the mediation effect of interest income and interest expenses on the relationship between inflation and banks' performance.

\section{Methodology}

This chapter represents the research methodology used in this study. The rationale of the research is to examine the effect of inflation on banks' performance. Previous studies conducted in this regard depict an ambiguousness in their results. This ambiguousness has occurred due to several reasons, and the ignorance of mediating effects of interest income and interest expenses is considered significant with this study. Hence, this section explains the data and the methods used in this mediation analysis.

This study investigated the direct effect of inflation on banks' performance due to the inconsistency of previous literature and mainly the indirect effect of inflation on banks' performance through interest expenses and interest income. Fig 1. depicts the hypothesized relationship among these variables.

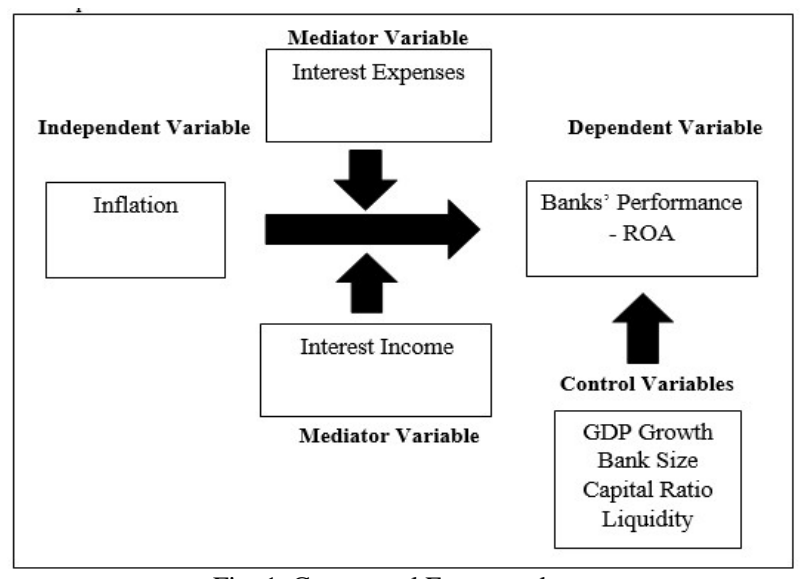

Fig. 1. Conceptual Framework.

Here, the researcher gathered secondary data from banks registered in Sri Lanka. It represents 12 Licensed Commercial Banks and 5 Licensed Specialized Banks. The data were collected from world bank indicators and annual reports of respective banks from 2011 to 2019. A Structural Equation Model (SEM) was used to represent the hypothesized relationships. Herein, the central equation developed to measure the direct effect of inflation on banks' performance. Meanwhile, the sub equations were developed to represent the mediation effect of interest income and interest expenses on banks' performance. To measure this SEM, the researchers have used the Seemingly Unrelated Regression model with OLS degree of freedom adjustment as the baseline model to enrich the findings. As the robust technique, the Three-Stage Least Squares model was used to confirm the results further.

$B P_{i t}=\beta_{0}+\beta_{1} I N F_{i t}+\beta_{2} \operatorname{LnINTE}_{i t}+\beta_{3} \operatorname{LnINTI}_{i t}+$
$\sum_{i=4}^{7} \beta_{i} C V_{i t}+e_{i t}$

where $B P_{i t}$ indicates the banks' performance which is measured by ROA, INF $F_{i t}$ indicates the inflation, LnINTE $_{i t}$ 
indicates the natural logarithm of interest expenses, LnINTI $_{i t}$ indicates the natural logarithm of interest income, $C V$ indicates the control variables (GDPG, BS, CR, LIQ), $\beta_{0}$ indicates the constant term, $\beta_{1}$ indicates the coefficient of inflation, $\beta_{2}$ indicates the coefficient of interest expenses, $\beta_{3}$ indicates the coefficient of interest income and $e_{i t}$ indicates the error term.

$$
\operatorname{LnINTE}_{i t}=\gamma_{0}+\gamma_{1} I N F_{i t}+\sum_{j=2}^{5} \gamma_{j} C V_{j}+e_{t}
$$

where LnINTE $_{i t}$ indicates the natural logarithm of interest expenses, $I N F_{i t}$ indicates the inflation, $C V$ indicates the control variables (BS, LIQ, CR, GDPG), $\Upsilon_{0}$ indicates the constant term, $\Upsilon_{l}$ indicates the coefficient of inflation and $e_{t}$ indicates the error term.

$$
\operatorname{LnINTI}_{i t}=\sigma_{0}+\sigma_{1} I N F_{i t}+\sum_{i=2}^{5} \sigma_{j} C V_{i t}+e_{i t}
$$

where, $\operatorname{LnINTI}_{i t}$ indicates the natural logarithm of interest income, $I N T_{i t}$ indicates the inflation, $C V$ indicates the control variables (BS, CR, LIQ, GDPG), $\sigma_{0}$ indicates the constant term, $\sigma_{1}$ indicates the coefficient of inflation and $e_{i t}$ indicates the error term.

To test the statistical significance of the mediation effect, the researcher used the Sobel test (1982). In this regard, the following equations can be used.

$\beta_{2} * \gamma_{1}$

$S_{\beta_{2} \gamma_{1}}=\sqrt{\gamma_{1}{ }^{2}} S_{\beta_{2}}^{2}+\beta_{2}^{2} S_{\gamma_{1}}^{2}+S_{\beta_{2}}^{2} S_{\gamma_{1}}^{2}$

$\left(\beta_{2} * \gamma_{1}\right) / S_{\beta_{2} \gamma_{1}}$

where $\beta_{2} * \gamma_{1}$ provides coefficient for the mediation effect of interest expenses (INTE). $S_{\beta_{2} \gamma_{1}}$ provides the standard error for the mediation coefficient. $\left(\beta_{2} * \gamma_{1}\right) / S_{\beta_{2} \gamma_{1}}$ indicates the $\mathrm{t}$ statistic.

$\mathrm{B}_{3} * \sigma_{1}$

$S_{\beta_{3} \sigma_{1}}=\sqrt{\sqrt{\sigma^{2}} S_{\beta_{3}}^{2}+\beta_{3}^{2} S_{\sigma_{1}}^{2}+S_{\beta_{3}}^{2}} S_{\sigma_{1}}^{2}$

$\left(\beta_{3} * \sigma_{1}\right) / S_{\beta_{3} \sigma_{1}}$

where, $\beta_{3} * \sigma_{1}$ provides coefficient for the mediation effect of interest income (INTI). $S_{\beta_{3} \sigma_{1}}$ provides the standard error for the mediation coefficient. $\left(\beta_{3} * \sigma_{1}\right) / S_{\beta_{3} \sigma_{1}}$ indicates the $\mathrm{t}$ statistic.

\section{DATA ANALYSIS AND DISCUSSION}

Several descriptive statistics were initially used to describe the general statistical properties of the selected variables. Table I depicts the results for the descriptive statistics.

The descriptive statistics reported in Table I show the main features of the collected data and provide a detailed understanding of inflation, interest income, interest expenses, and the performance of the banks. The reported results indicated that the variations of these variables are not much significant except in inflation. The mean inflation is 5.1 for the period, and it depicts a very high standard deviation. Therefore, inflation can be considered significantly volatile during the period.

\begin{tabular}{ccccc}
\multicolumn{5}{c}{ TABLE I: DESCRIPTIVE STATISTICS } \\
\hline Variable & Mean & Std. Dev. & Min & Max \\
\hline INF & 5.1 & 2.02 & 2.1 & 7.7 \\
INTI & 23.7 & 1.3 & 20 & 26 \\
INTE & 23.2 & 1.4 & 19 & 26 \\
ROA & 0.01 & 0.01 & -0.02 & 0.1 \\
ROE & 0.1 & 0.1 & -0.1 & 0.4 \\
LIQ & 0.7 & 0.1 & 0.1 & 0.9 \\
CR & 0.1 & 0.1 & 0.01 & 0.4 \\
BS & 26.1 & 1.4 & 23.4 & 29.3 \\
GDPG & 5.0 & 2.2 & 2.3 & 9.2 \\
\hline
\end{tabular}

The correlation matrix was used to see the association among the variables. Table II presents the correlation coefficients. The results implied that inflation, interest income, and interest expenses positively associated with the banks' performance (ROA and ROE), while interest income and interest expenses were negatively associated with inflation. However, only interest expenses depict a

\begin{tabular}{|c|c|c|c|c|c|}
\hline & ROA & ROE & INF & INTI & INTE \\
\hline ROA & 1.0000 & & & & \\
\hline ROE & 0.4699 & 1.0000 & & & \\
\hline INF & $\begin{array}{c}0.1730 * \\
(0.009)\end{array}$ & $\begin{array}{l}0.0224 \\
(0.045)\end{array}$ & 1.0000 & & \\
\hline INTI & $\begin{array}{l}0.1239^{*} \\
(0.0000)\end{array}$ & $\begin{array}{l}0.6532 * \\
(0.0000)\end{array}$ & $\begin{array}{l}-0.1540 \\
(0.189)\end{array}$ & 1.0000 & \\
\hline INTE & $\begin{array}{c}0.0728 * * \\
(0.073)\end{array}$ & $\begin{array}{l}0.6106 \\
(0.325)\end{array}$ & $\begin{array}{c}-0.1425^{*} \\
(0.003)\end{array}$ & 0.9329 & 1.0000 \\
\hline
\end{tabular}
statistically significant association with inflation.

The results of the baseline model, SURE, reported in Table III shows that inflation positively influences Sri Lankan banks' performance. It indicates when inflation increases by $1 \%$ banks' performance increase by $0.001 \%$ while holding other predictors constant.

The results of the robust model, 3SLS, reported in Table III also show that inflation positively influences Sri Lankan banks' performance. Thus, the result of the baseline model was further confirmed by the robust model.

\begin{tabular}{ccccc}
\multicolumn{4}{c}{ TABLE III: RESULTS OF DIRECT EFFECT } \\
\hline \multirow{2}{*}{ Variables } & \multicolumn{2}{c}{$\begin{array}{c}\text { Baseline Model } \\
\text { (SURE) }\end{array}$} & \multicolumn{2}{c}{$\begin{array}{c}\text { Robust Model } \\
\text { (3SLS) }\end{array}$} \\
\cline { 2 - 5 } & ROA & ROE & ROA & ROE \\
\hline INF (Inflation) & $0.0011^{*}$ & $0.005^{*}$ & $0.0013^{*}$ & 0.0062 \\
INTE (Interest Expenses) & $-0.0029^{* *}$ & -0.0098 & - & - \\
INTI (Interest Income) & $0.0065^{*}$ & $0.0449^{*}$ & $0.2967 *$ & $0.1757^{*}$ \\
CR (Capital Ratio) & $0.0921^{*}$ & $-0.2221^{*}$ & $0.0922^{*}$ & $-0.2209^{*}$ \\
LIQ (Liquidity) & 0.0075 & -0.0414 & 0.007 & -0.4398 \\
\hline$*$ - significant at 95\%, ** - significant at 90\%. & &
\end{tabular}

As in Table IV, baseline model, the results of the mediation effect show that interest expenses negatively mediate inflation when determining the performance of banks. It means that inflation has a significant adverse effect on the performance of banks through the influence of interest expenses. This may be due to expansions in banks' savings following inflation. According to the Central Bank Report 2014 , if future inflation is expected to be higher than the desired rate, policy interest rates will rise. As a result, investors will allocate more money towards banks' savings. 
In turn, it will raise banks' expenses on savings interest.

When savings go up, banks' potential in money creation goes up, resulting in more loans to the customers. So, it leads to an increase in the interest income on lending. Although banks try to grant loans to the customers, customers may not interest in obtaining loans as they have to spend substantial interest expenses. Thus, the effect of inflation on banks' performance may not be significant in an inflationary situation. This study further confirms the above arguments as the mediation effect of interest income is not statistically significant. However, the results show a positive coefficient for the mediation effect. It means that inflation has a positive effect on the performance of banks through the influence of interest income on banks' lending. In the robust model, the researcher has derived the same results for the mediation effect, and therefore, this result can be further confirmed.

\begin{tabular}{|c|c|c|c|c|c|c|}
\hline \multicolumn{7}{|c|}{ TABLE IV: RESULTS OF MEDIATION EFFECT } \\
\hline \multicolumn{7}{|c|}{ Baseline Model (SURE) } \\
\hline $\begin{array}{l}\text { Dependent } \\
\text { Variable }\end{array}$ & $\begin{array}{l}\text { Mediator } \\
\text { Variable }\end{array}$ & $\begin{array}{c}\text { Effect of Mediator } \\
\text { on ROA }\end{array}$ & $\begin{array}{l}\text { Effect of INF } \\
\text { on Mediator }\end{array}$ & $\begin{array}{l}\text { Mediation Effect } \\
\text { from Sobel }\end{array}$ & $\begin{array}{l}\text { Std } \\
\text { Error }\end{array}$ & t-value \\
\hline \multirow{2}{*}{ ROA } & INTE & $-0.0029 * *$ & $0.0577 *$ & $-0.0002 * *$ & 0.0001 & -1.4859 \\
\hline & INTI & $0.0065^{*}$ & 0.0221 & 0.0001 & 0.0001 & 1.2019 \\
\hline \multirow{2}{*}{ ROE } & INTE & -0.0098 & $0.0559 *$ & -0.0006 & 0.0006 & -0.8877 \\
\hline & INTI & $0.0449 *$ & 0.0202 & 0.0009 & 0.0008 & 1.1270 \\
\hline \multicolumn{7}{|c|}{$\begin{array}{l}\text { Robust Model (3SLS) } \\
\end{array}$} \\
\hline $\begin{array}{l}\text { Dependent } \\
\text { Variable }\end{array}$ & $\begin{array}{l}\text { Mediator } \\
\text { Variable }\end{array}$ & $\begin{array}{c}\text { Effect of Mediator } \\
\text { on ROA }\end{array}$ & $\begin{array}{l}\text { Effect of INF } \\
\text { on Mediator }\end{array}$ & $\begin{array}{l}\text { Mediation Effect } \\
\text { from Sobel }\end{array}$ & $\begin{array}{c}\text { Std } \\
\text { Error }\end{array}$ & t-value \\
\hline \multirow{2}{*}{ ROA } & INTE & $-0.0297 *$ & $0.0527 *$ & $-0.0016^{*}$ & 0.0010 & -1.6534 \\
\hline & INTI & $0.0348 *$ & 0.0191 & 0.0007 & 0.0007 & 0.9793 \\
\hline \multirow{2}{*}{ ROE } & INTE & $-0.1757^{*}$ & $0.0527 *$ & $-0.0093^{* *}$ & 0.0057 & -1.6122 \\
\hline & INTI & $0.2209 *$ & 0.0191 & 0.0042 & 0.0043 & 0.9878 \\
\hline
\end{tabular}

$*$ - significant at $95 \%, * *$ - significant at $90 \%$.

\section{CONCLUSION}

The main intention of this study was to examine the effect of inflation on banks' performance in Sri Lanka. Most of the previous researchers have thoroughly studied the direct effect of inflation on banks' performance. However, identifying the need for further investigating the channels through which inflation influences the banks' performance, this study analyzes the mediation effect of interest income and expense in the said relationship.

The results for the direct effect indicated that inflation significantly and positively influences banks' performance. Therefore, it confirms the Tan \& Floros [2], Chioma, Adanma, \& Clementina [14] and Khan, et al. [15].

In the case of mediators, results revealed that interest expenses carry a significantly negative effect while interest income carried a positive but insignificant effect of inflation to the banks' performance. Therefore, this study confirms an overall negative effect from inflation to the banks' performance. This is mainly due to the practice followed by the Central Bank of Sri Lanka. According to CBSL Report 2014, it tends to increase the interest rates following the inflationary situations anticipated. Thus, savings are encouraged through higher interest rates while bank lending have the other effect. However, this is not an acceptable economic situation as the current practice have failed to encourage the investors in further expanding their investments.

\section{REFERENCES}

[1] K. Kosmidou, S. Tanna, \& F. Pasiouras, "Determinants of profitability of domestic UK commercial banks: panel evidence from the period 1995-2002" In Money Macro and Finance (MMF) Research Group Conference, Vol. 45, 2005, pp. 1-27.

[2] Y. Tan \& C. Floros (2012). Bank profitability and inflation: the case of China. Journal of Economic Studies, 39(6), pp. 675-696.

[3] B. Guru, J. Staunton, B. Balashanmugam, "Determinants of Commercial Bank Profitability in Malaysia" Paper presented at the 12th Annual Australian Finance and Banking Conference, Sydney, Australia, 2002, pp. 16-17.

[4] R. Cameron, Banking lending and Economic Development: Some Lessons of History- New York: Oxford University Press, 1972, pp. 8896.

[5] Canutillo, Miguel and J. Wright, "How do Firms Choose their Lenders? An Empirical Investigation," Review of Financial Studies, 13, 2000, pp. $155-189$

[6] F. Sufian, \& R. R. Chong (2008). Determinants of bank profitability in a developing economy: empirical evidence from the Philippines" Asian Academy of Management Journal of Accounting \& Finance, 4(2), pp. 91-112.

[7] C. M. Kumar, G. Kiran, \& K. Manikumar "Effect of inflation on banks performance" International Conference on Recent Innovations in Science, Engineering and Management, 2017, pp. 253-263.

[8] B. Griffiths, Inflation: The Price of Property, London: Weidenfield and Nicolson Limited. London, 1977, ch. 4.

[9] B. George. (2000). A Transaction Cost Approach to the Theory of Investment Decision, Journal of Finance, 31: pp. 215-231.

[10] A.J. Haggler, Inflation Theory and Policy, Great Britain: London: Macmillan, 1977, ch 2.

[11] J. P. Jarrett \& J. G. Selody, "The productivity-inflation nexus in Canada, 1963-1979, Review of Economics and Statistics, vol. 64(3), 1982, pp. 67-71.

[12] V. E. I. W. Weersainghe, \& T. R. Perera (2013). Determinants of profitability of commercial banks in Sri Lanka. International Journal of Arts and commerce, 2(10), pp. 141-170.

[13] V. Flamini, M. L. Schumacher, \& M. C. A. McDonald, The determinants of commercial bank profitability in Sub-Saharan Africa, 2009, pp. 9-15.

[14] Chioma, D. O., Adanma, S. E., \& Clementina, N. O. (2014). Empirical Study of the Impact of Inflation on Bank Performance: Implication for Investment Decision Making in Banking Industry in Nigeria. Humanity \& Social Sciences Journal, pp. 69.

[15] Khan, W. A., Shahid, M., Bari, R., Anam, W., Shehzad, N., \& Siddique, S. (2014). Impacts of Inflationary Trends on Banks' Performance (Large Banks Segment) in Pakistan. International Journal of Accounting and Financial Reporting, pp. 305.

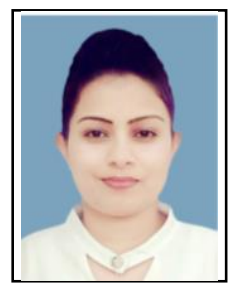

Madhusha C. Amarasena was born in Ratnapura, Sri Lanka, on $01^{\text {st }}$ May 1992 and obtained the first degree, B.Sc. Honors in Banking and Insurance with a Second-Class Upper Division from the Sabaragamuwa University of Sri Lanka in 2018 as well as won the Gold Medal for the best performance of the degree. Currently, she is reading M.Sc. in Applied Finance from University of Sri Jayewardenepura, Colombo in 2021. Currently, she is working as a TEMPORARY LECTURER at the Department of Accountancy and Finance, Faculty of 
Management Studies, Sabaragamuwa University of Sri Lanka. She has started her career with Union Assurance PLC as a Business Development Officer as well as with National Development Bank PLC as a Credit Officer. Her research interests are Banking and Insurance.

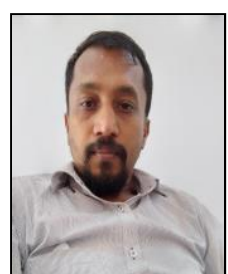

Ushan I. Peiris was born in Panadura, Sri Lanka, on $24^{\text {th }}$ August 1980 and obtained the first degree, B.Sc. Honors in Financial Management with a Second-Class Upper Division from the Sabaragamuwa University of Sri Lanka in 2006. He has completed MSc. in Financial Mathematics at the University of Moratuwa and his doctoral of philosophy $(\mathrm{PhD})$ in Economics from Universiti Putra Malaysia.

Currently, he is working as a Senior Lecturer at the Department of Accountancy and Finance, Faculty of Management Studies, Sabaragamuwa University of Sri Lanka. He has carried out several pieces of research and publication in different areas of economics and finance, such as Trade Integration, Monetary Integration, Stock Market volatility $\&$ integration, and Foreign Direct Investment. 